\title{
Promoting Ksatria Bela Negara comic through the Webtoon for the prevention and control Covid-19
}

\author{
Leni Anggraeni ${ }^{1}$, Cecep Darmawan ${ }^{1}$, Sri Wahyuni Tanshzil ${ }^{1}$, Edah Jubaedah ${ }^{1}$ \\ ${ }^{1}$ Departemen Pendidikan kewarganegaraan, Universitas Pendidikan Indonesia, Bandung, Indonesia
}

\begin{abstract}
ABSTRAK
Masa pandemi Covid-19 begitu masif, menjadi dasar bagi seluruh stakeholders untuk bahu membahu dalam menemukan solusi, baik dalam bentuk preventif (pencegahan) maupun kuratif (penyembuhan). Salah satu media edukasi yang strategis digunakan dalam pendekatan pencegahan dan penanggulangan Covid-19 bagi generasi digital natives saat ini yaitu melalui komik digital atau webtoon. Komik dalam bentuk digital memiliki banyak keunggulan dibandingkan dengan komik cetak. Berdasarkan hal tersebut, penelitian bertujuan untuk mengetahui bagaimana dampak promosi Komik Kesatria Bela Negara melalui Webtoon sebagai Media Edukasi Pencegahan dan Penanggulangan Covid-19 bagi masyarakat. Metode yang digunakan adalah Research and Development (R\&D) dengan menggunakan model pengembangan Waterfall. Hasil tinjauan ini menunjukkan bahwa dengan mempromosikan komik kesatria bela negara melalui webtoon mampu menjadi media persuasi untuk edukasi mencegah dan menanggulangi Covid-19. Edukasi Kreatif yang ditawarkan dari komik kesatria bela negara merancang pembaca webtoon untuk lebih dekat dengan cerita dan karakter karena lebih manusiawi, sehingga mampu memperlihatkan efek yang ditimbulkan dalam bentuk respons, baik kognitif (pengembangan pengetahuan), afektif (melalui sikap positif) serta konasi (tindakan sebagai hasil dari rangsangan sikap positif) terkait pencegahan dan penanggulangan Covid-19.
\end{abstract}

\section{ABSTRACT}

During the Covid-19 pandemic becomes the basis for all stakeholders to find solutions, both in the form of preventive (prevention) and curative (cure). One of the strategic educational media used to prevent and overcome covid-19 for the current generation of digital natives is through digital comics or webtoons. Comics in digital form has many advantages over printed comics. Based on this, the research aims to find out how the impact of the promotion of the National Defense Knight Comics through the Webtoon as an educational medium for preventing and controlling Covid-19 for the community. The method used is Research and Development (R\&D) using the Waterfall development model. The results of this review show that promoting comics of state defense knights through webtoons can become a medium of persuasion for education on preventing and overcoming Covid-19. The innovative education offered by the knight Bela Negara comic designs webtoon readers to be closer to the story and characters because it is more humane, so that they are able to show the effects in the form of responses, both cognitive (knowledge development), affective (through positive attitudes) and connective (action as the results of stimulating positive attitudes) related to the prevention and handling of covid-19
Article History:

Submitted : :13-03-2021

Revised

20-03-2021

Accepted

: 25-03-2021

Keywords:

komik digital, kesatria bela negara, webtoon, media edukasi, covid-19

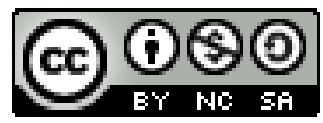

Cite in APA ${ }^{7 \text { th }}$ :

Anggraeni, L., Darmawan, C., Tanshzil, S. W., \& Jubaedah, E. (2021). Promoting Ksatria Bela Negara comic through the webtoon for the prevention and control Covid-19. Jurnal Civics: Media Kajian Kewarganegaraan, 18(1), 138-147. https://doi.org/10.21831/jc.v18i1.39377

Korespondensi: Leni Anggraeni, I_anggraeni@upi.edu, Departemen Pendidikan kewarganegaraan, Universitas Pendidikan Indonesia, Bandung, Indonesia

Copyright (C) 2021. Jurnal Civics: Media Kajian Kewarganegaraan. 


\section{Pendahuluan}

Usaha yang maksimal dalam mencegah penyebaran Corona Virus Disease 2019 (Covid-19) demi mengoptimalkan fase pencegahan perlu dilakukan melalui pendekatan informasi dan edukasi, mendirikan pos komando pencegahan Covid-19 memperbaiki komunikasi mengenai Covid-19 (Suni, 2020). Berdasarkan data World Health Organization (WHO) telah mengumumkan status pandemic global untuk virus corona atau juga disebut corona Covid-19. Dimana jumlah kasus terinfeksi dari hari ke hari semakin meluas dan meningkat.

Penanganan wabah ini telah dilakukan melalui berbagai kebijakan dalam berbagai dimensi, salah satunya dalam bidang Pendidikan melalui optimalisasi peranan teknologi komunikasi. Munculnya komik dalam bentuk digital menjadi salah satu alternatif promosi edukasi dalam pencegahan dan penanganan pandemic ini. Dalam beberapa tahun terakhir, semakin banyak penelitian yang menunjukkan efektifitas komik sebagai alat pendidikan dalam bidang kesehatan (Green \& Myers, 2010; McNicol, 2017). Komik digital (webtoon) merupakan salah satu media strategis dalam pencapaian komunikasi kesehatan, yaitu sebuah media yang digunakan untuk menyampaikan pesan berisi hal -hal terkait kesehatan kepada masyarakat (Lesmono et al., 2018; Park et al., 2016). Salah satu diantaranya adalah pesan edukasi terkait wabah Covid-19 yang sedang melanda seluruh negara di dunia.

Komik memberikan dampak tampilan yang lebih menarik, menyenangkan dan aktif (Nurhayati, 2020). Komik dirancang dengan bentuk yang mudah ditangkap dan dimengerti agar pembaca dapat tertarik dan senang melihat gambar daripada tulisan (Miranda et al., 2018). Komik mempunyai peranan dalam pencapaian aspek edukasi terutama dalam aspek afektif dengan cerita yang mudah dipahami karena mengintegrasikan dengan karakter melalui tokoh dan jalan cerita (Puspitorini et al., 2014). Keunggulan ini secara teoretis mampu mengarahkan individu pada pencapaian respons baik kognitif (dengan peningkatan pemahaman), afektif (memunculkan sikap dalam bentuk penilaian positif) serta konasi (menstimulus munculnya tindakan sesuai dengan pesan yang disampaikan) terkait pencegahan dan penanganan wabah Covid-19.

Secara Garis besar, terdapat dua kategori komik yang berfokus pada Kesehatan yang muncul dalam literatur kedokteran (Ashwal \& Thomas, 2018), yaitu: (1) riwayat tentang kesehatan pribadi, pengalaman medis atau penyakit, dan (2) komik pendidikan kesehatan yang dirancang untuk mendidik individu. kategori pertama, yaitu komik riwayat pribadi menceritakan kisah tentang pengalaman perawatan kesehatan seseorang, missal mom's cancer dan our cancer years (Fies, 2009; Pekar \& Brabner, 1994). Genre komik ini berfokus pada pengalaman orang tertentu, yang akan berbeda secara factual dari pasien lainnya. Kategori kedua, yaitu komik pendidikan (edukasi) kesehatan yang secara langsung menjelaskan informasi medis

Berdasarkan hal ini, peneliti tertarik untuk melaksanakan kajian terkait dampak promosi Komik Kesatria Bela Negara sebagai media edukasi untuk optimalisasi pendekatan edukasi pencegahan dalam penyebaran virus Covid-19.

\section{Metode}

Metode penelitian yang digunakan adalah Research and Development (R\&D) dengan menggunakan model pengembangan Waterfall atau dikenal dengan istilah metode pengembangan system SDLC (System Development Life Cycle), dengan 6 bagian yang meliputi: Investigasi, Analisis, Design, Testing, implementasi dan pemeliharaan. Dengan tahapan dan rincian partisipan yang meliputi: 
Gambar 1

Tahapan dan Partisipan

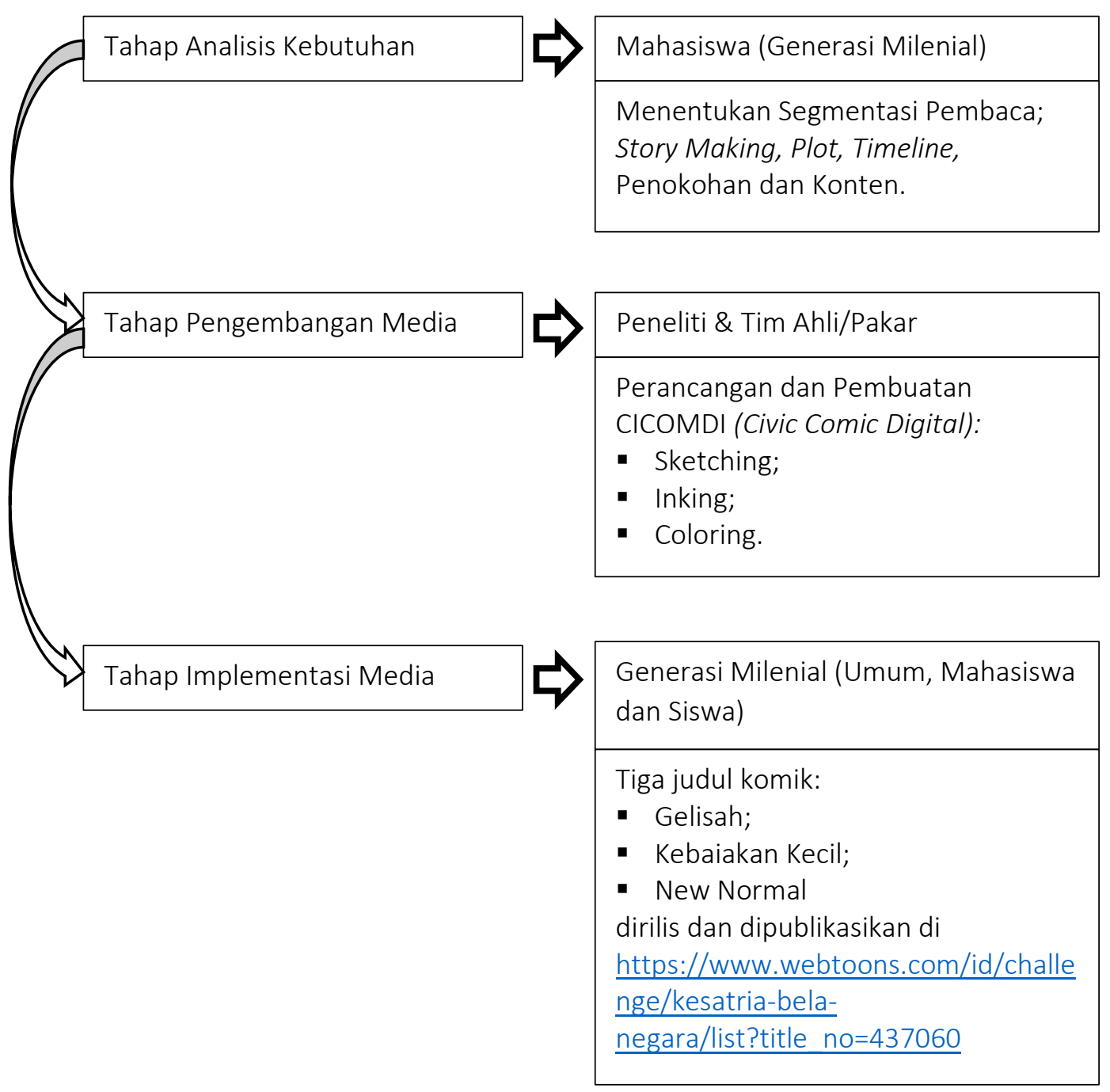

(Sumber: Dikembangkan oleh Tim Peneliti, 2020)

\section{Hasil dan Pembahasan}

Penguatan dan pelaksanaan sosialisasi pencegahan penyebaran virus Covid-19 dapat dilakukan dengan berbagai cara. Salah satunya dapat diterapkan melalui pengembangan edukasi dan Informasi (Suni, 2020). Penguatan dalam mengedukasi mengenai Covid-19 merupakan bagian yang tidak terlepas dari usaha fase pencegahan, yang dilakukan dengan meningkatkan komunikasi dan edukasi informasi sehingga tidak menimbulkan kepanikan di tengah masyarakat akibat adanya informasi yang tidak benar (Andriani, 2020). Penerimaan informasi bukan hanya bisa diakses melalui media yang informatif, tetapi juga melalui media yang menarik dan komunikatif. Salah satu upaya yang dapat ditempuh dalam fase pencegahan dengan edukasi yakni membaca webtoon komik kesatria bela negara.

\section{Kelebihan dan Keutamaan Komik Digital atau Webtoon}

Komik digital atau webtoon saat ini menjadi salah satu trending topik di beberapa negara seperti Korea, Amerika Utara, dan beberapa negara Asia Lainnya (Choi, 2016; Kim \& Yu, 2019). Istilah yang digunakan berbeda-beda, seperti di Amerika Utara dikenal dengan istilah komik digital, ecomisc, atau webcomic, sedangkan istilah webtoon sendiri berasal dari Korea Selatan. 
Hakikat Webtoon adalah sebuah komik yang didesain dalam bentuk digital. Webtoon menjadi sebuah format komik yang telah bertransformasi menjadi bentuk digital serta mampu di nikmati melalui alat elektronik tertentu (Petersen, 2010). Webtoon menjadi salah satu solusi dalam media edukasi yang menarik karena webtoon adalah kombinasi antara web dan kartun (comic), menjadi aplikasi yang gratis untuk dibaca dengan penggunaan yang mudah dimana pun dan kapan pun. Hal ini mampu menjawab kebutuhan masyarakat saat ini yang sudah sangat terfokus pada gedget atau handphone yang terkoneksi dengan internet, sehingga setiap hari orang dapat belajar melalui handphone mereka. Generasi saat ini sejatinya adalah penduduk asli di era digital, terlahir hingga dibesarkan dalam perkembangan teknologi yang begitu pesat (Ntobuo et al., 2018). Perkembangan ini yang menghasilkan generasi hyper-kognitif yang nyaman menggali informasi dari berbagai sumber dan mengombinasikan kehidupan virtual dengan nyata. Kehadiran webtoon sebagai media edukasi dalam berbagai bidang kehidupan merupakan sebuah jawaban atas keunikan karakteristik generasi ini.

Keunggulan webtoon dalam pandangan McCloud (2008) dibandingkan dengan komik cetak diantaranya adalah (1) lebih murah, (2) tahan lama, (3) bersifat interaktif, (4) lebih dinamis, (5) setiap serinya akan berubah dalam tampilannya, (6) serta mudah diakses. Webtoon lebih murah, karena seseorang hanya memerlukan jaringan internet untuk dapat menikmati cerita serta pesan yang terkandung di dalam nya (Lestari \& Irwansyah, 2020). Dokumentasi webtoon lebih aman dan tahan lama, karena tersimpan dalam web tertentu yang dapat diakses kapan pun dan dimana pun. Keunggulan lain dari komik digital atau webtoon yaitu dapat dikembangkan serta dipadukan dengan programming sehingga akan terdapat suara, Gerakan, bahkan progres cerita di dalam komik tersebut. Webtoon juga dapat dipadukan melalui pendekatan virtual reality dan augmented reality, dengan narasi komik yang terkoneksi dengan dunia nyata secara real (Mustaqim \& Kurniawan, 2017). Dengan perkembangan teknologi dan informasi, maka komik tipe ini akan semakin berkembang menjawab permasalahan dan kebutuhan masyarakat.

Line webtoon adalah platform dengan akses digital yang dapat diakses melalui telepon selular dengan aplikasi komik yang mempunyai banyak genre serta mempunyai banyak cerita dalam setiap episodenya, menjadikannya komik yang menghadirkan nilai-nilai pendidikan dalam kehidupan sehari-hari dengan berbagai tema yakni nilai persahabatan, kerja keras, kebersamaan, kegigihan dan kepribadian pantang menyerah (Jatnika \& Hermawan, 2018; Nurcahyani et al., 2018).

\section{Webtoon sebagai Sarana Media Edukasi Covid-19}

Penggunaan media dalam edukasi bidang Kesehatan memiliki tujuan untuk membangun perhatian pada satu masalah tertentu agar pembaca memahami serta terjadi perubahan dalam pengetahuan serta sikap individu pada arah tujuan yang telah ditetapkan. Yang tentunya harus didukung melalui ragam media yang dapat diakses secara mudah (Salaudeen et al., 2013; Tumigolung et al., 2013), seperti leaflet, video atau film (Wirawan et al., 2014), komik dan lainnya yang dapat membantu proses edukasi pada individu.

Komik digital atau Webtoon mampu memberikan sarana informasi dan edukasi melalui perpaduan warna, huruf, kesesuaian gambar dan kata, serta substansi materi, sehingga pembaca dengan mudah menyerap percepatan informasi yang beredar dengan konsep cerita dan penokohan (Rahman \& Triadi, 2019). Sifatnya sederhana, ringkas dan mudah dicerna dalam menyajikan pesan yang besar melalui kombinasi Bahasa verbal dan visual, sehingga mempercepat pembaca untuk paham akan pesan yang dimaksud yang dapat mengarahkan pembacanya untuk mengikuti arahan yang telah dirancang sejak awal (Rachman \& Damaianti, 2019). Dalam beberapa tahun terakhir, semakin banyak penelitian yang menunjukkan efektifitas komik sebagai alat pendidikan dalam bidang kesehatan (Green \& Myers, 2010; McNicol, 2017). Komik digital 
diposisikan sebagai salah satu media strategis dalam pencapaian komunikasi Kesehatan, yaitu sebuah media yang digunakan untuk menyampaikan pesan berisi hal -hal terkait Kesehatan dari pemberi pesan kepada penerimanya, salah satu diantaranya adalah pesan edukasi terkait wabah Covid-19 yang sedang melanda seluruh negara di dunia.

Secara Garis besar, terdapat dua kategori komik yang berfokus pada Kesehatan yang muncul dalam literatur kedokteran (Ashwal \& Thomas, 2018), yaitu: (1) riwayat tentang kesehatan pribadi, pengalaman medis atau penyakit, dan (2) komik pendidikan kesehatan yang dirancang untuk mendidik individu. kategori pertama, yaitu komik riwayat pribadi menceritakan kisah tentang pengalaman perawatan kesehatan seseorang, missal mom's cancer dan our cancer years (Fies, 2009; Pekar \& Brabner, 1994). Genre komik ini berfokus pada pengalaman orang tertentu, yang akan berbeda secara factual dari pasien lainnya. Kategori kedua, yaitu komik pendidikan (edukasi) kesehatan yang secara langsung menjelaskan informasi medis. Dimana komik bentuk ini dirancang untuk menyampaikan informasi atau menghasilkan respons estetika pada pembacanya serta untuk mengomunikasikan informasi yang akurat dan relevan tentang hal serius dan topik teknis selama beberapa decade dan lintas budaya (Yu, 2015). Oleh karenanya, penggunaan media komik digital mampu menjadi sarana edukasi yang efektif dan efisien dalam tindakan preventif bagi penyebaran wabah penyakit, salah satunya adalah Covid-19 yang sedang mewabah di seluruh penjuru dunia.

Cover komik Webtoon dalam riset ini dibuat dengan format dari webtoon yakni 436 px x 436 px dengan format square. Dengan konsep Kesatria Bela Negara yang mempunyai makna seolah menjadi kesatria dalam pemberantasan Covid-19. Hal tersebut dapat dilihat dalam gambar cover di bawah ini.

Gambar 2.

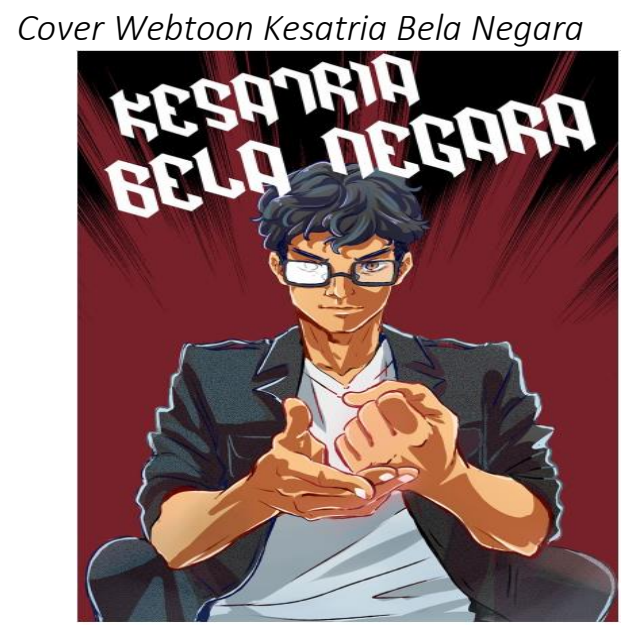

(Sumber: Dikembangkan oleh tim peneliti, 2020)

Fase Pencegahan Covid-19 menjadi salah satu faktor yang penting dalam musibah ini. Edisi khusus webtoon tentang Covid-19 dengan judul "Gelisah" ini menceritakan tentang banyak penimbun masker di tengah kondisi genting karena wabah Covid-19. Hal ini diketahui setelah mengunjungi beberapa apotek, dimana stok masker telah habis semua. Ribam sebagai seorang mahasiswa mempunyai perasaan yang campur aduk terhadap kondisi pandemi yang dilaluinya. Terlebih lagi, ketika melihat Mang Dadang (penjual warung kecil dekat rumah Ribam) tidak berjualan, sehingga Ribam mempunyai keinginan untuk membantu melawan kondisi ini. Pada beberapa saat kemudian, Ribam dihubungi untuk menjadi relawan di rumah sakit dengan menggunakan beberapa ketentuan diantaranya physical distancing, menggunakan baju hamzat diantaranya pelindung wajah, pelindung mata, masker, pita relawan, sarung tangan, sepatu boot. 
Pada saat itulah Ribam menjadi Kesatria Bela Negara yang membantu negara untuk mengobati pasien yang terpapar virus Covid-19. Beberapa gambar yang mewakili kondisi tersebut bisa dilihat di bawah ini:

Gambar 3.

Inti Cerita Webtoon Kesatria Bela Negara Seri Covid-19

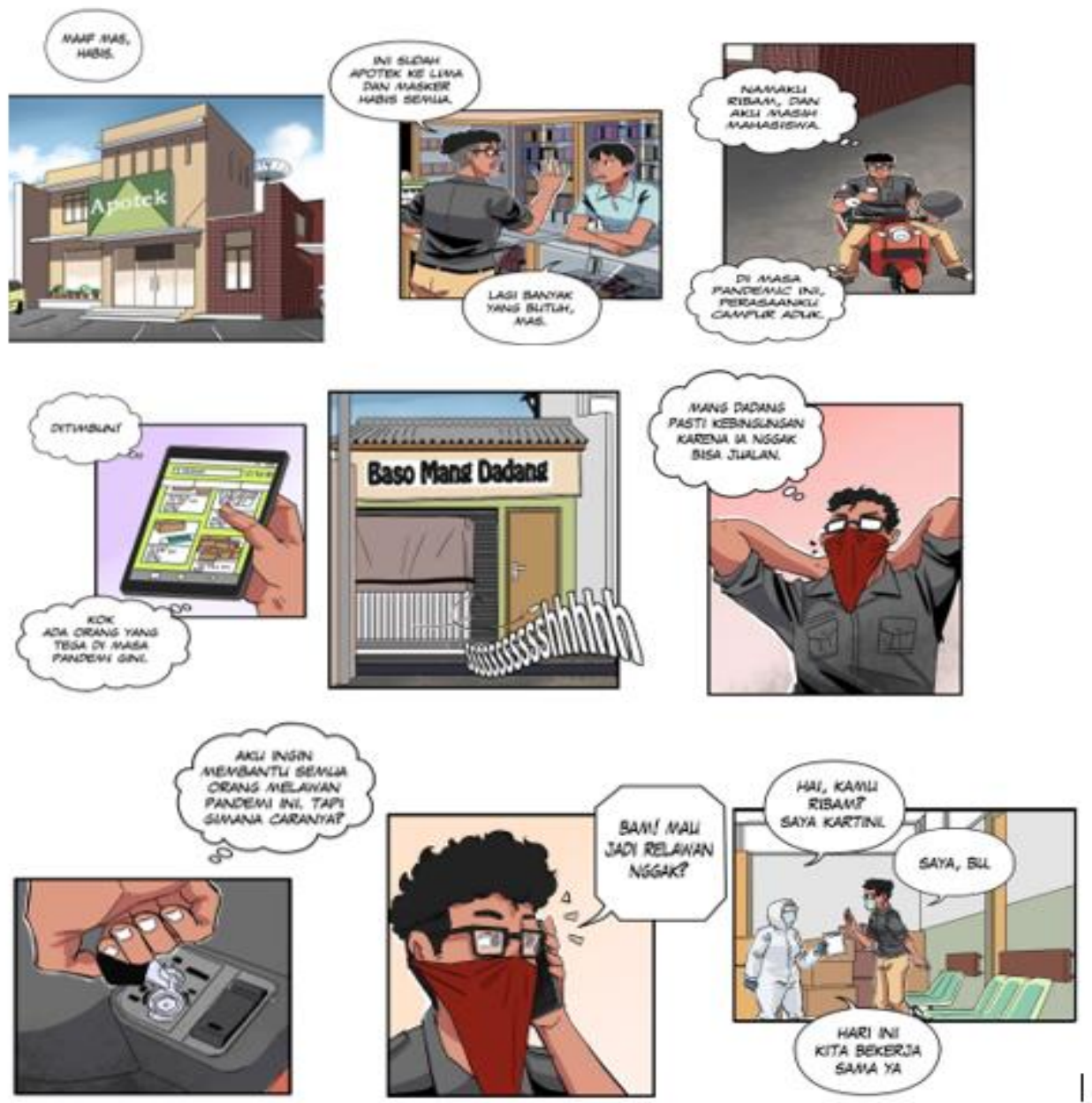

(Sumber: Dikembangkan oleh tim peneliti, 2020)

Pada aspek webtoon ini adanya desain atau karakter yang membuat komik memperlihatkan sifat dan latar belakang dahulu, webtoon juga memiliki kebebasan dibandingkan dengan komik, pada webtoon ini juga menggunakan warna yang kompleks agar lebih dekat dengan jiwa emosional pembaca dan dapat diterima dengan alur yang slice of life. Transisi dari tokoh ke tokoh dengan percakapan dua karakter atau lebih menggunakan angle yang berbeda sehingga visualisasi webtoon dapat menggunakan scene yang berbeda dengan pergantian waktu dan tempat yang terukur.

Dalam pandangan Ashwal dan Thomas (2018) menyatakan bahwa kekuatan komik sebagai media edukasi dapat diidentifikasi melalui beberapa point penting, yaitu pertama, tata bahasa komik bisa memfasilitasi pemahaman individu ke level yang lebih tinggi. Kedua, ketelitian dalam merancang interaksi kata dan gambar mampu meningkatkan literasi kesehatan. Ketiga, hubungan spasial antar ilustrasi dapat menciptakan dinamika penggambaran waktu, yang dapat digunakan untuk membantu menjelaskan informasi sebab-akibat terkait dengan pengobatan atau perilaku kesehatan tertentu. Keempat, teknik grafis komik adalah penjajaran berbagai gambar di halaman tertentu yang berguna untuk melakukan kontras keadaan sehat dan tidak sehat atau penyakit, 
missal kondisi orang normal dengan orang yang terinfeksi Covid-19. Dengan demikian, penggunaan media komik digital menjadi salah satu sarana percepatan peningkatan pemahaman masyarkat terhadap penyebaran Covid-19 yang sedang mewabah saat ini.

Pesan yang ingin disampaikan dalam webtoon ini adalah memberikan edukasi dan informasi kepada pembaca agar dapat mengetahui dan memahami terkait kondisi pandemic Covid-19 yang sedang mewabah, serta memperlihatkan bahwa diluar sana banyak pahlawan yang sedang berjuang Bersama - sama untuk melawan virus ini. Edukasi kreatif konsep yang ditawarkan dari komik ini merancang pembaca webtoon untuk lebih dekat dengan cerita dan karakter karena lebih manusiawi. Sehingga dapat mengarahkan peningkatan kemampuan tidak hanya pada pemahaman saja, lebih dari itu mampu membangun sikap serta merangsang keterlibatan baik secara aktif maupun pasif dalam menangani wabah pandemik Covid-19 ini.

\section{Respons Pembaca Webtoon Komik Kesatria Bela Negara}

Hasil akhir dari perancangan webtoon diunggah melalui webtoon LINE dengan penayangan setiap episode sehingga dapat dilihat dari target pembaca serta respons dari pembaca. Respons dalam Kamus Besar Bahasa Indonesia dimaknai dengan "tanggapan; reaksi; jawaban". Hal tersebut muncul sebagai bentuk reaksi terhadap suatu pesan yang diterima oleh individu. Respons juga dapat dimaknasi sebagai "umpan balik" (feedback) yang dapat menentukan baik tidaknya sebuah komunikasi yang dibangun.

Berdasarkan gambaran respons terhadap webtoon kesatria bela negara, dapat diketahui bahwa pembaca memberi respons positif terhadap pesan yang dibawakan. hal ini terlihat dari berbagai tanggapan melalui berbagai bentuk penilaian melalui pengungkapan kata, seperti "keren", "cerita yang bagus", "cerita yang ringan serta menarik", "dapat menerima nilai-nilai positif yang disampaikan dalam webtoon kesatria bela negara". Melalui respons tersebut dapat diketahui bahwa media webtoon kesatria bela negara telah mampu memberi efek pada pencapaian tujuan kognitif, afektif serta konasi. Hal ini dapat dijelaskan melalui pendekatan Cognitive Response Model (Model Respons Kognitif) yaitu sebuah pendekatan teori yang digunakan untuk mengetahui berjalannya proses kognisi pada sebuah pesan yang disampaikan melalui sebuah media, melalui tahap pengolahan infomasi (kognisi), perubahan sikap terhadap pesan yang dibawakan (afeksi) yang akhirnya menuju proses pengambilan keputusan (konasi) (Belch \& Belch, 2009). Lebih rinci hal tersebut digambarkan oleh Chaferespon (Mulyana \& Rakhmat, 1990; Rakhmat, 1999) yang membedakan respons kedalam tiga jenis, yaitu:

1. Respons kognitif, adalah sebuah respons yang ditimbulkan atas rangsangan pesan eksternal yang berkaitan erat dengan pengetahuan serta informasi seseorang tentang satu hal tertentu. Indicator adanya respons ini adalah perubahan terhadap pemahaman individu atau khalayak.

2. Respons afektif, adalah respons yang ditimbulkan atas rangsangan eksternal yang terkait erat dengan emosi, sikap dan penilaian seseorang terhadap sesuatu pesan.

3. Respons Konatif, adalah respons dari rangsangan pesan eksternal yang berhubungan dengan perilaku nyata dalam bentuk Tindakan individua tau khalayak.

Respons kognitif yang muncul sebagai efek dari pesan yang telah disampaikan, memberi pemaknaan dalam membentuk pemikiran dan penilaian seseorang. Pemikiran tersebut merupakan sebuah hasil dari proses kognitif yang berasal dari akumulasi pengetahuan berdasarkan pengalaman masa lalu yang mengarahkan individu pada bentuk penerimaan atau penolakan terhadap pesan yang diterima. Terpaan webtoon kesatria bela negara dalam posisinya sebagai bentuk informasi eksternal yang mengalami akumulasi dengan pengalaman masa lalu individu akan membentuk sikap positif atau negative terhadap pesan yang disampaikan. Sikap 144 
positif dari individu merupakan bentuk pengejawantahan penilaian individu dalam domain afeksi yang dapat mempengaruhi keputusan individu untuk melaksanakan pesan- pesan edukatif yang terkandung dalam webtoon tersebut.

Respons positif yang diperlihatkan melalui jejak digital pada kolom komentar dapat memperlihatkan efektifitas media tersebut dalam menyampaikan edukasi dan informasi kepada pembaca terkait pandemic Covid-19 yang sedang mewabah, serta menyadari bahwa diluar sana banyak pahlawan yang sedang berjuang bersama sama untuk melawan virus ini. Pendekatan humanis yang dimunculkan pada karakter Ribam memperkuat pengaruh afeksi sebagai penjabaran hakikat manusia sebagai makhluk individu dan social, membangun sikap toleransi, saling menyayangi dan bekerja sama untuk mengatasi permasalahan bersama yaitu wabah pandemic Covid-19. Komik menawarkan kesempatan untuk membangun kesadaran diri, kepastian, empati, persahabatan dan untuk mengeksplorasi dampak penyakit dalam sebuah hubungan tertentu (McNicol, 2017). Sikap positif tersebut akan memberi pengaruh signifikan terhadap keputusan individu untuk melaksanakan pesan-pesan yang dimunculkan dalam webtoon. Secara general efek yang ditimbulkan atas pesan yang ingin disampaikan melalui webtoon kesatria bela negara mampu mengapai respons individu pada ranah kognitif, afektif dan konasi.

\section{Simpulan}

Perancangan media edukasi komik ini dapat menunjang pencegahan penyebaran virus Covid-19. Komik webtoon ini sangat digemari karena aksesnya yang gratis dan mudah diakses dapat dibuktikan dengan banyaknya orang yang sudah mengakses webtoon dan menyukainya. Webtoon Kesatria Bela Negara memberikan edukasi dan mempermudah khalayak dalam mempelajari segala sesuatunya terutama dalam usaha edukasi pencegahan Covid-19 yang dapat dilihat dari 3 respons, yaitu respons kognitif, afektif dan konasi.

\section{Referensi}

Andriani, H. (2020). Effectiveness of large-scale social restrictions (PSBB) toward the new normal era during covid-19 outbreak: A mini policy review. Journal of Indonesian Health Policy and Administration, 5(2), 61-65. https://doi.org/10.7454/ihpa.v5i2.4001

Ashwal, G., \& Thomas, A. (2018). Are comic books appropriate health education formats to offer adult patients? AMA Journal of Ethics, 20(2), 134-140. https://doi.org/10.1001/journalofethics.2018.20.2.ecas1-1802

Belch, G. E., \& Belch, M. A. (2009). Advertising and promotion: An integrated marketing communications perspective. McGraw-Hill. http://lib.ui.ac.id

Choi, J. (2016). "Awl is piercing me and society": Webtoon as a popular adult education tool in South Korea. In B. Chang \& M. Misawa (Eds.), Proceedings of the 8th Asian Diaspora Adult Education Pre-conference.

Fies, B. (2009). Mom's cancer.

Green, M. J., \& Myers, K. R. (2010). Graphic medicine: Use of comics in medical education and patient care. BMJ, 340(mar03 2), c863-c863. https://doi.org/10.1136/bmj.c863

Jatnika, A. W., \& Hermawan, F. F. (2018). Menjadi lelaki sejati: maskulinitas dalam komik daring webtoon Indonesia. Mudra Jurnal Seni Budaya, 33(1), 60-66. https://doi.org/10.31091/mudra.v33i1.158

Kim, J.-H., \& Yu, J. (2019). Platformizing webtoons: The impact on creative and digital labor in South Korea. Social Media + Society, 5(4), 1-11. https://doi.org/10.1177/2056305119880174 
Lesmono, A. D., Bachtiar, R. W., Maryani, \& Muzdalifah, A. (2018). The instructional-based androweb comics on work and energy topic for senior high school students. Jurnal Pendidikan IPA Indonesia, 7(2), 147-153. https://doi.org/10.15294/jpii.v7i2.14245

Lestari, A. F., \& Irwansyah, I. (2020). Line webtoon sebagai industri komik digital. SOURCE : Jurnal IImu Komunikasi, 6(2), 134-148. https://doi.org/10.35308/SOURCE.V6I2.1609

McCloud, S. (2008). Understanding comics. Paw Prints.

McNicol, S. (2017). The potential of educational comics as a health information medium. Health Information \& Libraries Journal, 34(1), 20-31. https://doi.org/10.1111/hir.12145

Miranda, P. H., Waluyanto, H. D., \& Zacky, A. (2018). Perancangan buku komik sebagai media informasi mengenai dampak game terhadap perilaku sosial anak. Jurnal DKV Adiwarna, 1(12), 9. http://publication.petra.ac.id/index.php/dkv/article/view/7259

Mulyana, D., \& Rakhmat, J. (1990). Komunikasi antarbudaya. Remaja Rosdakarya.

Mustaqim, I., \& Kurniawan, N. (2017). Pengembangan media pembelajaran berbasis augmented reality. Jurnal Edukasi Elektro, 1(1), 59-72. https://doi.org/10.21831/jee.v1i1.13267

Ntobuo, N. E., Arbie, A., \& Amali, L. N. (2018). The development of gravity comic learning media based on gorontalo culture. Jurnal Pendidikan IPA Indonesia, 7(2), 246-251. https://doi.org/10.15294/jpii.v7i2.14344

Nurcahyani, D., Maulida, N., \& Prasetya, K. H. (2018). Analisis nilai-nilai pendidikan karakter tokoh utama guru honorer dalam komik pak guru inyong berbasis webtoon karya anggoro ihank. Jurnal Basataka (JBT), 1(2), 35-40. https://doi.org/10.36277/basataka.v1i2.26

Nurhayati, E. (2020). Meningkatkan keaktifan siswa dalam pembelajaran daring melalui media game edukasi Quiziz pada masa pencegahan penyebaran Covid-19. Jurnal Paedagogy.

Park, Y., Yim, S., \& Jeong, H.-S. (2016). Imagining through webtoon: Webtoon-focused convergence education project in middle school. Cartoon and Animation Studies, 45, 451477. https://doi.org/10.7230/koscas.2016.45.451

Pekar, H., \& Brabner, J. (1994). Our cancer year. Running Press.

Petersen, R. (2010). Comics, manga, and graphic novels: A history of graphic narratives. ABC-CLIO. https://books.google.co.id/books?id=Hr7aZh6oonoC

Puspitorini, R., Prodjosantoso, A. K., Subali, B., \& Jumadi, J. (2014). Penggunaan media komik dalam pembelajaran ipa untuk meningkatkan motivasi dan hasil belajar kognitif dan afektif. Jurnal Cakrawala Pendidikan, 33(3), 413-420. https://doi.org/10.21831/cp.v3i3.2385

Rachman, R. S., \& Damaianti, V. S. (2019). Peran sains-teknologi dalam pembelajaran BIPA: Pengembangan webtoon berbasis komunikasi lintas budaya sebagai antisipasi gegar budaya. Konferensi Internasional Pengajaran Bahasa Indonesia Bagi Penutur Asing (KIPBIPA) XI, XI, 453-465.

Rahman, Y., \& Triadi, A. (2019). Perancangan cerita webtoon mengenai budaya palang pintu. Desain Komunikasi Visual, Manajemen Desain Dan Periklanan (Demandia), 4(1), 1-15. https://doi.org/10.25124/demandia.v4i01.1968

Rakhmat, J. (1999). Psikologi komunikasi. Remaja Rosdakarya.

Salaudeen, A., Musa, O., Akande, T., \& Bolarinwa, O. (2013). Effects of health education on cigarette smoking habits of young adults in tertiary institutions in a northern Nigerian state. 
Health Science Journal, 7(1), 54-67. https://www.hsj.gr/medicine/effects-of-healtheducation-on-cigarette-smoking-habits-of-young-adults-in-tertiary-institutions-in-anorthern-nigerian-state. php?aid=3068

Suni, N. S. P. (2020). Kesiapsiagaan Indonesia menghadapi potensi penyebaran corona. Pusat Penelitian Badan Keahlian DPR RI, XII(3), 13-18.

Tumigolung, H. C. S., Wungouw, H., \& Onibala, F. (2013). Pengaruh pendidikan kesehatan terhadap tingkat pengetahuan siswa tentang bahaya merokok di SMA Negeri 1 Manado. Nomor 1. Agustus, 1(1). https://ejournal.unsrat.ac.id/index.php/jkp/article/view/2186

Wirawan, S., Khairul Abdi, L., \& Sulendri, N. K. S. (2014). Penyuluhan dengan media audio visual dan konvensional terhadap pengetahuan ibu anak balita. Jurnal Kesehatan Masyarakat, 10(1), 80-87. https://doi.org/10.15294/kemas.v10i1.3073

Yu, H. (2015). The other kind of funnies: Comics in technical communication (1st ed.). Routledge. https://www.routledge.com/The-Other-Kind-of-Funnies-Comics-in-TechnicalCommunication/Yu/p/book/9780895038401 